\title{
Nutrient intake and protein turnover
}

\section{By P. J. Reeds and M. F. Fuller, Rowett Research Institute, Bucksburn, Aberdeen $A B 2$ $9 S B$}

Changes in body protein mass are the result of the simultaneous synthesis and degradation of proteins. Because the rates of these processes greatly exceed those of either protein intake or protein deposition, the turnover of body protein dominates the turnover of free amino acids in the body.

Even in rapidly growing animals much of the synthesis of body protein is related to the replacement of cellular protein lost by inevitable catabolism (Reeds et al. I980) and only part of the process is functionally related to growth. Although the intake of nutrients has a major impact on the rate of protein turnover in the body, as animals mature and their maximum growth rate declines, the increases in body protein synthesis which accompany increases in intake above those required for maintenance become progressively smaller. The limit is reached in the adult where an increase in intake above that required for nitrogen equilibrium has little effect on the rate of protein synthesis (Table I). In theory, both protein synthesis and degradation could be increased to the same extent, as part of a thermogenic response for example, but such an occurrence seems rare.

Although the extent to which nutrient intake affects the synthesis and degradation of body protein depends on the stage of development, at a given developmental stage the nutritional and physiological status of the individual can also influence the response to a subsequent change in intake. Clugston \& Garlick $(1982 b)$, for example, have shown that the immediate response of protein turnover to a meal is profoundly modified by the subject's preceeding intake of protein.

Table I. The effect on nitrogen balance and body protein synthesis of an increase in intake above that required to maintain $N$ equilibrium in individuals of different ages

\begin{tabular}{|c|c|c|c|c|c|}
\hline \multirow[b]{2}{*}{ Species } & \multirow[b]{2}{*}{ Age or wt } & \multicolumn{3}{|c|}{ Increase (g protein $/ \mathrm{kg}$ per $\mathrm{d}$ ) in: } & \multirow[b]{2}{*}{ Reference } \\
\hline & & Protein & $\mathrm{N}$ balance & $\begin{array}{c}\text { Protein } \\
\text { synthesis }\end{array}$ & \\
\hline Pig & $\begin{array}{l}30 \mathrm{~kg} \\
60 \mathrm{~kg} \\
90 \mathrm{~kg}\end{array}$ & $\begin{array}{l}3 \cdot 1 \\
2 \cdot 7 \\
2 \cdot 1\end{array}$ & $\begin{array}{l}2 \cdot 2 \\
0.6 \\
0.3\end{array}$ & $\begin{array}{l}7 \cdot 0 \\
3 \cdot 1 \\
I \cdot 8\end{array}$ & $\begin{array}{l}\text { P. J. Reeds, M. F. Fuller and A. } \\
\text { Cadenhead (unpublished results) } \\
\text { Whole diet }\end{array}$ \\
\hline Man & $\begin{array}{l}23 \text { years } \\
40 \text { years }\end{array}$ & $\begin{array}{l}0.9 \\
0.5\end{array}$ & $\begin{array}{l}0.3 \\
0\end{array}$ & $\begin{array}{l}0.4 \\
0\end{array}$ & $\begin{array}{l}\text { Motil, Matthews et al. ( } 198 \mathrm{1}) \\
\text { Protein alone } \\
\text { Clague et al. }\left(\mathrm{I}_{98}\right) \text { Whole diet }\end{array}$ \\
\hline Cattle & $550 \mathrm{~kg}$ & 0.4 & 0 & 0 & $\begin{array}{l}\text { Reeds, } \emptyset \text { rskov et al. (1981) } \\
\text { Protein alone }\end{array}$ \\
\hline
\end{tabular}


Similarly, Clague et al. ( $198_{3}$ ) have proposed that the $\mathrm{N}$ loss associated with operative trauma results from both a reduction in body protein synthesis, related specifically to the associated change in nutritional status, and to a pathological increase in the rate of protein catabolism due to the traumatic condition itself.

\section{Food intake}

Many measurements of body protein turnover have been made under a quasisteady-state of food and protein intake. This is not a true reflection of the pattern of food intake in the normal individual, particularly man. In Fig. I (Parsons et al. I983) are shown the diurnal changes in $\mathrm{N}$ excretion that occur in 'meal fed' children. The excretion of urea is increased when food is being ingested but despite this, $\mathrm{N}$ is retained during the 'fed' period and lost during the night time fast. Previous work with adults (Garlick et al. 1980; Clugston \& Garlick, I982a; Rennie et al. 1982; Table 2) has demonstrated the same point. While these results show that the changes in $\mathrm{N}$ retention are associated with marked changes in body protein synthesis, the changes in the rate of protein degradation are more equivocal in as much as both increases and decreases have been found in different studies (Table 2). It is possible that this lack of agreement is due to the unsatisfactory nature of the methods that were available for the measurement of protein degradation in these studies. All reported measurements of body protein turnover were calculated from the flux of a single amino acid and the calculation of protein degradation is critically dependent on the assumption that is made with regard to the relationship between the labelling of free amino acids in blood and tissues. Clugston \& Garlick (1982a) have pointed out that, whereas an error in this assumption affects the magnitude of changes in protein synthesis it does not alter the direction of any estimated change but a similar error has the potential to alter the direction of the apparent changes in protein degradation. In the study of Rennie et al. (1982), body amino acid flux was calculated from measurements of

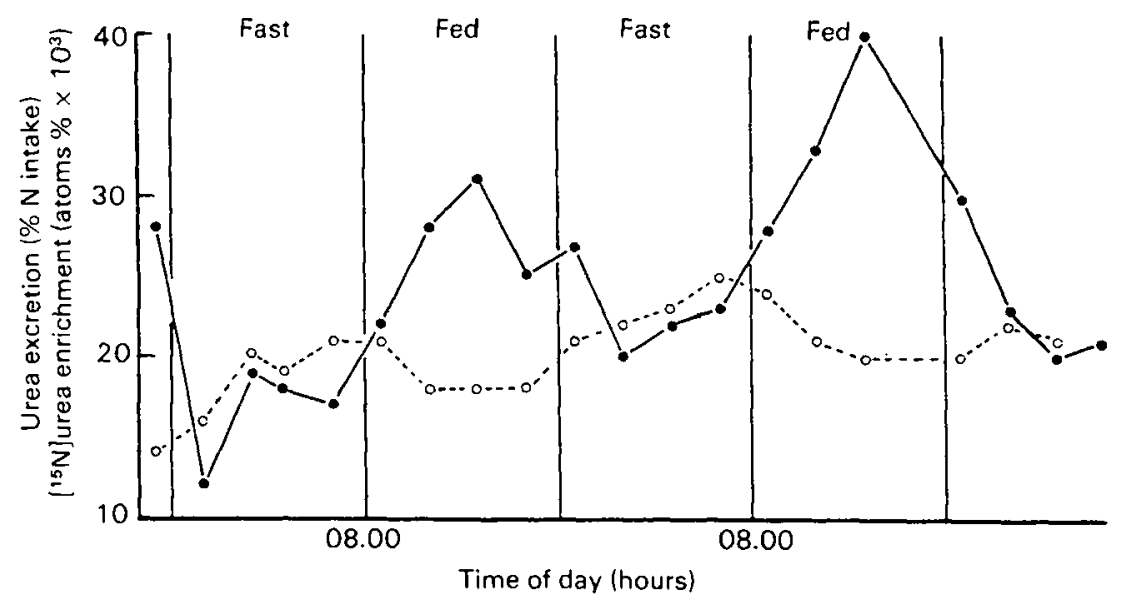

Fig. I. Changes in urea excretion $(\bullet)$ and isotope abundance $(O)$ in children receiving four meals between 08.00 and 20.00 hours. The children received a tracer dose of $\left[{ }^{15} \mathrm{~N}\right]$ glycine in frequent oral doses (after Parsons et al. 1983). 
Table 2. Protein synthesis, degradation and $N$ balance in fed and fasted adult humans

(All values as g protein $/ \mathrm{kg}$ per d)

\begin{tabular}{|c|c|c|c|c|c|c|}
\hline \multicolumn{2}{|c|}{ Balance } & \multicolumn{2}{|c|}{$\begin{array}{l}\text { Protein } \\
\text { synthesis }\end{array}$} & \multicolumn{2}{|c|}{$\begin{array}{l}\text { Protein } \\
\text { degradation }\end{array}$} & \multirow[b]{2}{*}{ Reference } \\
\hline Fed & Fast & Fed & Fast & Fed & Fast & \\
\hline$+1 \cdot 2$ & -0.6 & $3 \cdot 4$ & $2 \cdot 5$ & $2 \cdot 3$ & 3.0 & Clugston \& Garlick (1982a) \\
\hline$+1 \cdot 1$ & -0.7 & $4 \cdot 5$ & $3 \cdot 9$ & $3 \cdot 4$ & $4 \cdot 8$ & $\begin{array}{l}\text { Motil, Bier et al. (1 } 981 \text { ); Motil, Matthews et al. } \\
\text { (1981) Subjects receiving I } 5 \mathrm{~g} \text { protein } / \mathrm{kg} \text { per d }\end{array}$ \\
\hline+0.7 & -0.6 & $7 \cdot 1$ & $4 \cdot 2$ & $6 \cdot 4$ & 4.9 & Rennie et al. (1982) \\
\hline
\end{tabular}

the labelling of blood $\alpha$-keto-isocaproic acid which, being derived from the metabolism of intracellular leucine, may be a better estimate of the labelling of free leucine in the intracellular phase. As such we should, at present, accept that their observations of the changes in body protein degradation are the most valid, but more work on this is required.

One of the most striking observations of both Clugston \& Garlick (1982a) and Rennie et al. (1982) was the rapidity with which body protein synthesis and amino acid oxidation altered once food intake had ceased. It seems likely that this is a measure of the rapidity with which simple diets, ingested frequently, are cleared from the stomach. Results with meal fed rats (Garlick et al. 1973) also demonstrate that once food intake ceases, muscle protein synthesis falls only when the stomach has emptied of food. Clearly, changes in the signals that link the intake of nutrients and the turnover of body protein occur rapidly once the absorption of nutrients ceases.

The information in Table 2 relates only to the changes that occur in the whole body and this, of course, represents the sum of the activities of many different cells. Are all the major tissues equally affected?

Recent evidence in man (Rennie et al. 1982) shows that the changes that occur in skeletal muscle protein synthesis on fasting were proportionally greater than in the body as a whole. Thus, on fasting, whole body protein synthesis fell by $35 \%$ and the rate of protein synthesis in skeletal muscle by $50 \%$. This implies that protein synthesis in other tissues changes to a lesser extent and direct evidence from rats confirms this conclusion (Table 3 ). Indeed, it seems that the rate of protein synthesis in the skeletal musculature is inherently more sensitive to nutritional change than it is in other tissues. It could be concluded that muscle protein deposition is also more sensitive to nutritional deprivation than protein deposition in, say, the skin or gastrointestinal tract (other major contributors to body protein mass). However, changes also occur in protein degradation and these minimize the short-term loss of protein. Although skeletal muscle may be an important contributor to a gain or loss of body protein this is a reflection more of its large contribution to body protein mass than of an exaggerated proportional gain or loss of protein in the musculature. 
Table 3. Tissue protein synthesis (\% protein pool synthesized/d) in young rats either receiving an adequate diet, fasted or receiving a low-protein diet (after McNurlan et al. 1982)

$\begin{array}{lccc}\text { Tissue } & \text { Normal } & \text { Fasted } & \begin{array}{c}\text { Protein- } \\ \text { deficient }\end{array} \\ \text { Muscle } & 17 & 6 & 4 \\ \text { Liver } & 86 & 72 & 69 \\ \text { Jejunal mucosa } & 123 & 92 & 95\end{array}$

The effect of longer term changes in food intake

Information on the effects of changes in the whole diet, both above and below that required for energy equilibrium, are shown in Fig. 2. Both in the adult (below maintenance) and in the immature (above maintenance) there are co-ordinated changes in both protein synthesis and degradation. The slope of the line relating intake to protein synthesis is steeper than that relating intake to protein degradation and it seems that, quantitatively, protein synthesis is the most important factor controlling $\mathrm{N}$ retention under these circumstances. However, it is equally important to recognize that the slopes of both lines are positive, i.e. that increased intake results in higher rates of both protein synthesis and protein degradation and this is true both above and below body $\mathrm{N}$ equilibrium.

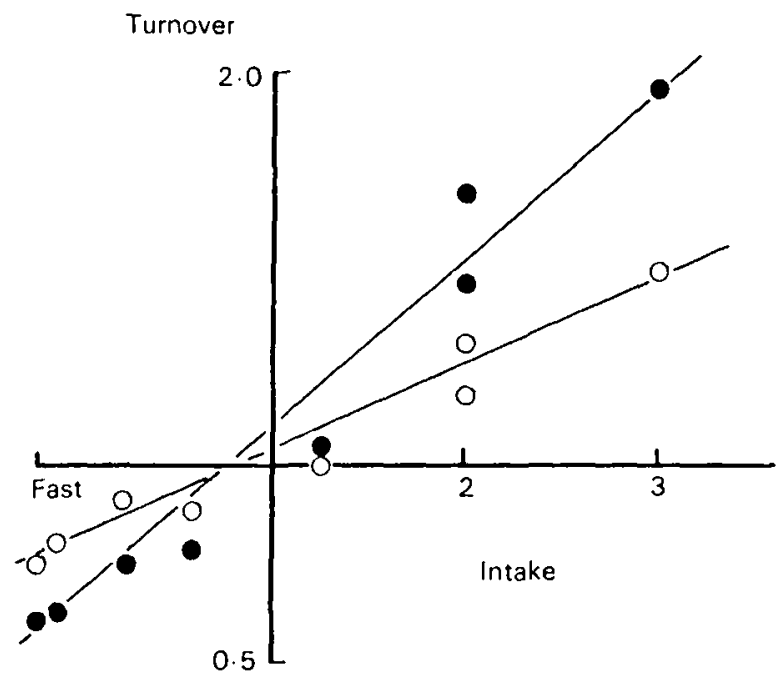

Fig. 2. Protein synthesis $(\Theta)$ and breakdown $(O)$ in relation to the combined intake of non-protein energy and protein. Values for synthesis, breakdown and intake are expressed as proportions of the values at energy equilibrium. Above maintenance, the values are calculated from $M$. H. V. Golden, A. A. Jackson and D. I. M. Picou (personal communication); Reeds et al. (1980); Motil, Bier et al. (198r) and Motil, Matthews et al. (1981); and below maintenance, from Garlick et al. (1980); Motil, Bier et al. (1981); Motil, Matthews et al. (1981) and Clague et al. (1983). Values for prolonged fast from Winterer et al. ( 1980$)$.

The best lines are:

Protein synthesis $=0.65$ intake $( \pm 0.034)+0.18( \pm 0.06)$

Protein degradation $=0.46$ intake $( \pm 0.067)+0.30( \pm 0.11)$ 
In the experiments summarized in Fig. 2 it was food intake that was altered; that is, both protein and non-protein energy were increased in concert. Do these results represent separate responses to dietary protein and energy or are the changes in the relationship between $\mathbf{N}$ retention, protein synthesis and protein degradation the same irrespective of the dietary change from which they result?

The problem, however, arises of how to compare the effects of changes in dietary energy and protein. Should the results be interpreted in terms of the response of $\mathrm{N}$ retention or in terms of changes in energy intake (the only satisfactory way by which changes in protein and non-protein energy intake can be 'normalized')? Regarding the first of these approaches, it appears that $\mathrm{N}$ retention by adults is less sensitive to a change in energy intake than it is to the intake of protein but this is not true for immature animals (Fuller \& Crofts, 1977). In Table 4 therefore, changes in protein synthesis and $\mathrm{N}$ retention are shown in relation to the change in metabolizable energy intake. These results suggest that protein and non-protein energy influence $\mathrm{N}$ retention by different mechanisms. In growing pigs, increases in dietary protein markedly stimulate both protein synthesis and degradation and the same seems true of adults below $\mathrm{N}$ equilibrium. Indeed, Clugston \& Garlick ( $1982 b$ ) propose that the immediate response to fasting in adult man is one related only to the change in protein intake. Furthermore, the results in Table 3 show that, in rats, ingestion of a protein-free diet is as effective in reducing protein synthesis as a total fast.

In contrast to these effects of dietary protein, changes in non-protein energy intake influence $\mathrm{N}$ retention in association with a small increase in the rate of protein synthesis and a small decrease in that of protein degradation. Even where marked changes in $\mathrm{N}$ retention have been effected, the changes in both protein synthesis and protein degradation barely attain statistical significance (Reeds,

Table 4. Changes in protein synthesis, degradation and balance ( $g$ protein/MY additional energy) following changes in either non-protein energy or protein intake

(Mean values with their standard errors)

\begin{tabular}{|c|c|c|c|c|c|c|c|c|c|}
\hline \multirow[b]{3}{*}{ Diet change } & \multicolumn{8}{|c|}{ Change in: } & \multirow{3}{*}{$\begin{array}{c}\text { Reference } \\
\text { group }\end{array}$} \\
\hline & \multicolumn{2}{|c|}{$\begin{array}{c}\text { Dietary } \\
\text { energy }(M J / d)\end{array}$} & \multicolumn{2}{|c|}{$\begin{array}{l}\text { Protein } \\
\text { synthesis }\end{array}$} & \multicolumn{2}{|c|}{$\begin{array}{l}\text { Protein } \\
\text { degradation }\end{array}$} & \multicolumn{2}{|c|}{$\begin{array}{l}\text { Protein } \\
\text { balance }\end{array}$} & \\
\hline & Mean & $\overrightarrow{\mathrm{SE}}$ & Mean & $\mathbf{S E}$ & Mean & $\mathbf{S E}$ & Mean & SE & \\
\hline $\begin{array}{l}\text { Energy } \\
\text { Protein }\end{array}$ & $\begin{array}{l}6 \cdot 4 \\
1.7\end{array}$ & $\begin{array}{l}0.7 \\
0.2\end{array}$ & $\begin{array}{r}6.2 \\
54 \cdot 0\end{array}$ & $\begin{array}{r}1.5 \\
18.0\end{array}$ & $\begin{array}{r}0.5 \\
31.0\end{array}$ & $\begin{array}{r}1.0 \\
18 \cdot 0\end{array}$ & $\begin{array}{r}3 \cdot 8 \\
23 \cdot 0\end{array}$ & $\begin{array}{l}1.6 \\
5 \cdot 0\end{array}$ & $\stackrel{\dagger}{\ddagger}$ \\
\hline
\end{tabular}

\footnotetext{
-Values calculated from Sim et al. (1979), Garlick et al. (1980), Winterer et al. (1980). All subjects were in a state of negative $\mathrm{N}$ balance.

†Values calculated from Motil, Bier et al. (198r) and Reeds, Fuller et al. (198r). All subjects in positive $\mathbf{N}$ balance.

$\ddagger$ Values calculated from Garlick et al. (1980), Winterer et al. (1980), Motil, Matthews et al. (198I), Reeds, Fuller et al. (198I). Motil's 'low' to 'adequate' diets were compared.
} 
Table 5. Changes in plasma protein synthesis in patients receiving, intravenously, either amino acids $(A A)$, dextrose + insulin $(D I)$ or both simultaneously (DIAA) (after O'Keefe et al. 198r)

\begin{tabular}{lccc} 
Protein & \multicolumn{3}{c}{$\begin{array}{c}\text { Change in rate of synthesis } \\
\text { (\% of control value) }\end{array}$} \\
\cline { 2 - 4 } Globin & AA & DI & DIAA \\
Albumin & +50 & -33 & -4 \\
+54 & --68 & +13
\end{tabular}

Fuller et al. 198I) and the change in protein synthesis is of the same order as that of $\mathrm{N}$ retention (Sim et al. 1979; Reeds, Fuller et al. 1981). This emphasizes the point that very small proportional changes in protein turnover have the potential to produce marked changes in both $\mathrm{N}$ retention and free amino acid concentrations.

\section{Possible mechanisms of control of protein turnover by nutrient intake}

One of the most striking conclusions that can be drawn from the results of Reeds, Fuller et al. ( $198 \mathrm{I}$ ) is that the effects of dietary protein and energy on protein metabolism are additive rather than interactive. Thus the responses of young pigs to increases in intake of the whole diet can be predicted from the separate responses to protein and energy. A similar conclusion can be drawn from the results obtained in postoperative patients reported by O'Keefe et al. (I98I) (Table 5). It appears then that the separate components of the diet affect the mechanisms that link nutrient intake to protein synthesis and degradation in different ways. In general terms there seem to be three main possibilities by which protein turnover could be modified by dietary intake. First, that the nutrients themselves are the main signal for the change in protein metabolism acting by a 'mass action' mechanism; second, that specific nutrients or their metabolites could act, in a manner analogous to allosteric modifiers of other enzymes, to amplify the protein synthetic or degradative responses to changes in extracellular substrate concentrations; third, that the changes in tissue metabolism are a response to hormonal signals which act on tissues either alone or synergistically with the nutrients or their metabolites.

The first of these possibilities seems unlikely. One striking feature of many of the observations on nutrient intake and protein metabolism is the small extent to which the concentrations of the main substrates are altered. For example, Millward et al. (1976) were unable to obtain any correlation between free amino acid concentrations in muscle and the rate of muscle protein synthesis under a number of circumstances. Similarly, there is no change in blood glucose concentrations in pigs receiving high-carbohydrate diets nor in ketone body concentrations in animals receiving high-fat diets despite the fact that marked changes in $\mathrm{N}$ retention can be effected by these dietary means. Even when the intake of protein is increased by $50 \%$, the changes in blood amino acid concentrations are small. Nevertheless, there is a considerable body of evidence from studies performed with 
isolated tissues that specific compounds, especially leucine and its metabolites, have effects on protein synthesis and degradation which are not directly related to their role as substrates for the processes concerned (Buse \& Reid, 1975; Tischler et al. 1982) and such observations lend support to the second mechanism. However, the changes in extracellular amino acid concentrations which are required to bring about changes in protein synthesis in vitro are much greater than the changes in blood amino acid concentrations which normally accompany changes in nutrient intake sufficient to alter the rates of protein synthesis and degradation in vivo. In addition, McNurlan et al. (I982) have been unable to demonstrate that the administration of a large dose of leucine affects the rate of protein synthesis in the skeletal muscle of rats even under conditions where the animals had suffered a depletion of body protein. Consequently it is difficult, at present, to conclude that changes in amino acid concentrations in general and in the concentration of leucir.e in particular are primary stimuli to the synthesis of body protein.

The third mechanism of control involves changes in the hormonal status of the individual but this does not deny the primary role of nutrient supply, as the nature and amounts of the nutrients absorbed from the gastrointestinal tract presumably provide the initial stimulus for a change in the pattern of hormonal secretion. However, both the identification of the critical hormones and the precise ways in which physiological variations in hormone concentrations influence protein turnover in the intact organism are far from certain. On the basis of correlations between food intake and their concentrations, four hormones seem worthy of immediate attention: insulin, cortisol (or corticosterone), pituitary growth hormone (acting perhaps via the somatomedins) and glucagon. Work in vitro has demonstrated effects of all these hormones on skeletal muscle protein synthesis but corresponding evidence in vivo is sparse (however, see Garlick et al. 1983). Correlations of hormonal changes with changes in urea synthesis and leucine turnover (Fig. 3) demonstrate the important point that a change in the concentration of a single hormone is not necessarily the most important factor but that the balance between catabolic (cortisol in Fig. 3) and anabolic (insulin) influences must be considered. In addition, the results show that the hormonal status of an animal, once it has adapted to a particular diet, may not be the same as that during the period of adaptation and it is possible that transient changes in the concentration of a hormone may affect the subsequent sensitivity of its target tissue.

Another approach to this problem is to study the metabolic effects of 'normal' variations in hormone concentrations. Virtually no work has been reported on the normal animal. Fuller et al. (1977) demonstrated that, in growing pigs, systemic administration of insulin was able to improve the rate of $\mathrm{N}$ retention in the short-term and Garlick et al. (1983) have demonstrated a stimulation of muscle protein synthesis by insulin in normal animals. A recent paper, unfortunately describing experiments on fasted animals, has reported the effects of high physiological levels of insulin in dogs treated with somatostatin. Interestingly, the 
(a)

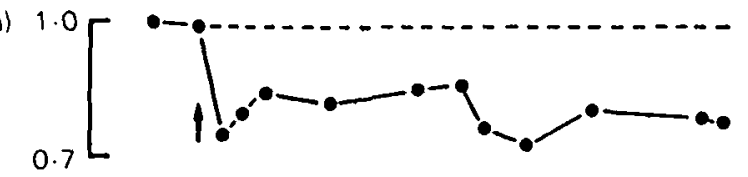

(b)

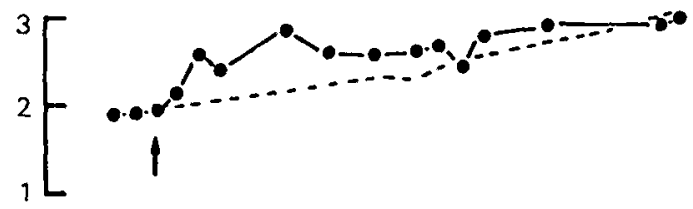

(c) ${ }^{60}[$

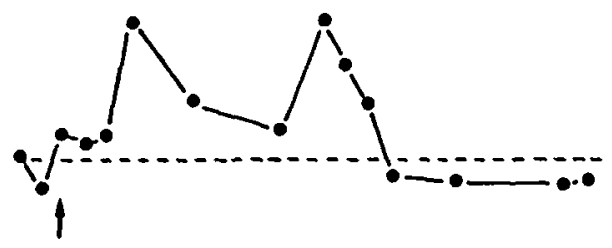

(d)

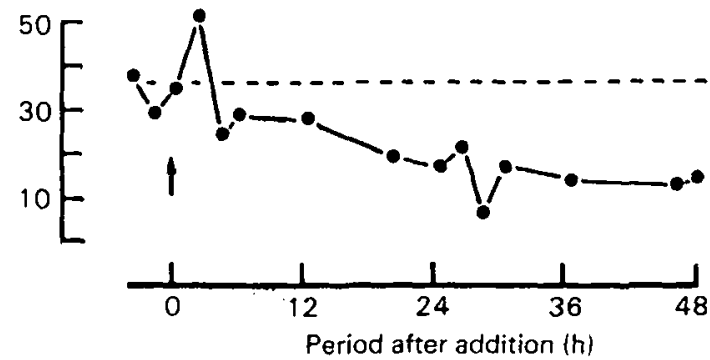

Fig. 3. Changes in (a) urea synthesis $(\mathrm{g} / \mathrm{h}$ ), (b) leucine specific radioactivity (disintegrations/min per nmol), (c) plasma insulin concentration $(\mu \mathrm{U} / \mathrm{ml})$ and (d) cortisol concentration $(\mathrm{ng} / \mathrm{ml})$ in pigs during a $4^{8}$ h period after receiving a carbohydrate supplemented diet (P. J. Reeds, M. F. Fuller, A. Cadenhead and S. M. Hay, unpublished results). The animals were fed each hour and were infused with $\left[{ }^{14} \mathrm{C}\right]$ urea and $\left[{ }^{3} \mathrm{H}\right]$ leucine $\left({ }^{\uparrow}\right.$, time of infusion). The dotted lines denote the values in pigs which did not receive an alteration in diet.

results of this study (Abumrad et al. 1982) are similar, with respect to the change in whole body leucine turnover, to those observed in pigs during the early part of the experiment illustrated in Fig. 3 .

Experiments designed specifically to investigate the effects of physiological variations in hormone concentrations on protein metabolism are a recent development and any comments on the significance of recent work are premature. However, the fact that attempts are being made to examine this aspect of the control of protein metabolism demonstrates that there is now confidence in the validity and sensitivity of the currently available techniques for the study of protein turnover in vivo. This is a measure of the extent to which the techniques have been developed in the last 5 years.

\section{Conclusion}

The quantity and nature of the major nutrients absorbed by the individual has a major influence on the accretion of body protein, and the nutritional status of the 
subject can have a significant influence on the responses to other factors including trauma. In man and other mammals, quantitatively the most important influence is the intake of protein. This seems to stimulate both protein synthesis and degradation. The intake of non-protein energy, while affecting $\mathrm{N}$ retention, appears to act in a manner different to that of dietary protein. These two dietary factors appear to have a summative, rather than an interactive, effect on protein turnover and may stimulate protein accretion via different mechanisms. The nature of these mechanisms is not certain but at present it does not seem to involve, primarily, changes in metabolite concentrations in systemic blood. Rather, changes in amino acid concentrations may represent the end-product of changes in the relative rates of tissue protein synthesis and degradation. This alone demonstrates the importance of understanding the control of the dynamics of body protein metabolism in order to maximize growth in the immature and minimize the loss of protein under catabolic conditions in both immature and adult individuals.

\section{REFERENCES}

Abumrad, N. N., Jefferson, L. S., Rannels, S. R., Williams, P. E., Cherrington, A. D. \& Lacy, W. W. (1982). f. clin. Invest. 70, $103 \mathrm{I}$.

Buse, M. G. \& Reid, S. S. (1975). F. clin. Invest. 56, 1250.

Clague, M. B., Keir, M. J., Wright, P. D. \& Johnston, 1. D. A. (1983). Clin. Sci. 65, 165.

Clugston, G. A. \& Garlick, P. J. (1982a). Human Nutrition:Clinical Nutrition 36C, 57 .

Clugston, G. A. \& Garlick, P. J. (1982b). Human Nutrition:Clinical Nutrition 36C, 39 I.

Fuller, M. F. \& Crofts, R. M. J. (1977). Br. F. Nutr. 38, 479.

Fuller, M. F., Weekes, T. E. C., Cadenhead, A. \& Bruce, J. B. (1977). Br. F. Nutr. 38, 489.

Garlick, P. J., Clugston, G. A. \& Waterlow, J. C. (1980). Am. Y. Physiol. 288, E235.

Garlick, P. J., Fern, M. \& Preedy, V. R. (1983). Biochem. F. 2 10, 669.

Garlick, P. J., Millward, D. J. \& James, W. P. T. (1973). Biochem. F. 136, 935.

McNurlan, M. A., Fern, E. B. \& Garlick, P. J. (I982). Biochem. F. 204, 831 .

Millward, D. J., Garlick, P. J., Nuanyelugo, D. O. \& Waterlow, J. C. (1976). Biochem. J. 156, 185.

Motil, K. J., Bier, D. M., Matthews, D. E., Burke, J. F. \& Young, V. R. (1981). Metabolism 30, 783 .

Motil, K. J., Matthews, D. E., Bier, D. M., Burke, J. F., Munro, H. N. \& Young, V. R. (I981). Am. f. Physiol. 240, E7 2.

O'Keefe, S. H. D., Moldawer, L. L., young, V. R. \& Blackburn, G. L. (1981). Metabolism 30, 1150.

Parsons, H. G., Wood, M. M. \& Peucharz, P. B. (1983). Can. F. Physiol. Pharmacol. 6r, 72.

Reeds, P. J., Cadenhead, A., Fuller, M. F., Lobley, G. E. \& McDonald, J. D. (1980). Br. F. Nutr. 43, 445 .

Reeds, P. J., Fuller, M. F., Cadenhead, A., Lobley, G. E. \& McDonald, J. D. (1981). Br. J. Nutr. 45, 539 .

Reeds, P. J., Ørskov, E. R. \& MacLeod, N. A. (I98I). Proc. Nutr. Soc. 40, 50A.

Rennie, M. J., Edwards, R. H. T., Halliday, D., Matthews, D. E., Wolman, S. L. \& Millward, D. J. (1982). Clin. Sci. 63, 519 .

Sim, A. J. W., Wolfe, B. M., Young, V. R., Clarke, D. \& Moore, F. D. (1979). Lancet i, 68.

Tischler, M. E., Desautels, M. D. \& Goldberg, A. L. (1982). F. biol. Chem. 257, 1613.

Winterer, J., Bistrian, B. R., Bilmazes, C., Blackburn, G. L. \& Young, V. R. (1980). Metabolism 29, 575 . 